\title{
Earning Management Actions and Conditional Revenue as Managerial Efforts to Maintain Bond Rating
}

\author{
ANDRIAWAN \\ IGNATIUS RONI SETYAWAN \\ UNTAR Jakarta
}

\begin{abstract}
The purpose of this study is to analyze factors affecting the Bonds rating of non-financial companies listed on the Indonesia Stock Exchange for the period 20122016. The sample was selected using a purposive sampling method that amounted to 30 companies - data processing techniques using multiple regression analysis what helped by the SPSS program. This study shows that partially the company's size, company's growth, and auditor size have a significant influence on bond rating, while earnings management has no significant effect on bond rating. This result supports Wajnsztajn \& Heintz's (2016) study that management will think twice about earnings management when rating bonds. This is based on the principle of transparency in corporate governance that the actual company's performance will better reflect the company's position as a good bond issuer. However, this study shows that the company's size, company's growth, and auditor size significantly affect the bond rating. This result proves that firm size, growth, and auditor size are essential factors in a bond rating. Without having to do earnings management, if the company has good size, growth, and auditors size-related, it will also be good to bond ratings according to these rating providers' criteria.
\end{abstract}

Keywords: Auditor Size, Bonds Rating, Earnings Management, Growth.

\begin{abstract}
Abstrak.Tujuan dari penelitian ini adalah melakukan analisis faktor-faktor yang mempengaruhi peringkat obligasi perusahaan non-keuangan yang terdaftar di Bursa Efek Indonesia untuk periode 2012-2016. Sampel dipilih menggunakan metode purposive sampling berjumlah 30 perusahaan. Teknik pengolahan data menggunakan analisis regresi berganda yang dibantu oleh program SPSS. Hasil penelitian ini menunjukkan bahwa secara parsial ukuran perusahaan, pertumbuhan perusahaan, dan ukuran auditor memiliki pengaruh signifikan terhadap peringkat obligasi, sedangkan manajemen laba tidak berpengaruh signifikan terhadap peringkat obligasi. Hasil ini mendukung studi Wajnsztajn \& Heintz (2016) bahwa manajemen akan berpikir dua kali tentang manajemen laba ketika menilai obligasi. Ini didasarkan pada prinsip transparansi dalam tata kelola perusahaan bahwa kinerja perusahaan yang sebenarnya akan lebih mencerminkan posisi perusahaan sebagai penerbit obligasi yang baik. Namun, penelitian ini menunjukkan bahwa ukuran perusahaan, pertumbuhan perusahaan, dan ukuran auditor masing-masing memiliki pengaruh signifikan terhadap peringkat obligasi. Hasil ini membuktikan sekali lagi bahwa dalam menentukan peringkat obligasi, faktor ukuran perusahaan, pertumbuhan dan ukuran auditor adalah
\end{abstract}

\footnotetext{
*Corresponding author: andrisanz91@gmail.com
} 
faktor yang sangat penting dalam peringkat obligasi. Tanpa harus melakukan manajemen laba maka jika perusahaan memiliki ukuran yang baik, pertumbuhan dan ukuran auditor terkait maka itu juga akan baik untuk peringkat obligasi sesuai dengan kriteria penyedia peringkat ini.

Kata Kunci: Manajemen Laba, Pertumbuhan, Peringkat Obligasi, Ukuran Auditor.

\section{Introduction}

Bond ratings are critical for investors because they can provide informative descriptions and provide signals about the possibility of a company's debt failure. Before deciding to buy bonds in a company, we should first know the reputation of these bonds. One of the media to observe the reputation of bonds circulating in the capital market is to pay attention to the bond rating agency's ratings.

Kim et al. (2013) stated that the rating agency's task is to collect necessary information and monitor the company's business and financial risks. Credit analysts from rating agencies will meet regularly with management and evaluate the company's strategic plans, latest developments, performance results against expectations, and potential weaknesses of each division. The rating agency also evaluates the management of financial projections and strategic planning management during the rating process, which are not available to the public.

Therefore, management tends to regulate financial statements by implementing earnings management. With this earnings management, it is hoped that it can provide a signal to the rating agency regarding the company's positive financial performance so that it can provide the best rating. With a good rating, this will undoubtedly increase trust and maximize funds to the company.

In the Graham and Harvey (2001) survey, managers answered that they prioritize their credit rating in deciding the company's capital structure policy. They try to manipulate real activities in meeting their profit targets. Kim et al. (2013) also proved that companies are proven to carry out earnings management through the accrual method to maintain credit ratings. Furthermore, Yogy and Sari (2010) also researched earnings management and bond ratings with a sample of non-financial companies on 
the IDX in 2005-2009. The research results are that the company is proven to manipulate earnings through short-term discretionary accruals when the issuance of bonds. The company is proven to manipulate earnings through long-term discretionary accruals at the time of issuance of bonds. Then Crabtree et al. (2014) and Sari \& Bandi (2010) show a relationship between earnings management and bond ratings, where the correlation is negative. So it proves that managers' efforts to manage earnings in the financial reporting period can give negative results because it covers company performance by distorting earnings quality and increasing information asymmetry, which can be interpreted as opportunistic behavior of managers. Sumanti's study (2018) has also proven an earnings game terminology that focuses on earnings management and market expectations. Then there are several ways of manipulating earnings, namely Accrual Earnings Management (AEM), Real Earnings Management (REM), and Formal \& Informal communication to guide analyst forecast downward (DFG).

Therefore, increasing the risk of earnings management can result in a lower credit rating. However, in Wajnsztajn \& Heintz (2016) found no relationship between earnings manipulation and credit ratings because the rating of securities agents will compare again with financial projections made by management compared to actual achievements from historical events that occur then take into account the business and industry risks that will affect the company itself.

This study is motivated by research from Sari \& Bandi (2010) in which earnings management comes from the discretionary accrual component. This study also refers to Stubben (2010), where the measurement of earnings management uses a proxy for discretionary revenues. In the research, Stubben (2010) has proven that the revenue model has proven to produce less bias, is more specific, and more robust than using the accrual model. The modeling of the single component of profit contributes a more specific key factor to the profit component, which provides an insight into how that profit is managed. Income is the ideal component to prove it because it is the company's largest profit component.

Then Roychowdhury (2006) has also proven that company managers manipulate real activities to prevent loss reporting. Furthermore, Zhu \& Lu (2013) have proven that 
some managers have manipulated earnings in real terms before mergers and acquisitions. Hätty \& Åkesson (2015) have also proven that the revenue model is more able to explain earnings management than other models.

There are two types of formulas in the discretionary revenue model introduced by Stubben (2010). First is the revenue model, which focuses on income that has a direct relationship with accounts receivable. Second, namely the conditional revenue model, this model was redeveloped with the addition of company size (size), company age (age), and gross margin (GRM), which are thought to be used in detecting accrual earnings management (PSAK No. 1 Revision 2013) regarding granting credit that has a direct impact on accounts receivable. Firm size is a proxy for financial strength. Company age is a proxy for the company's stage in the business cycle. As a proxy for the company's operational performance compared with competitors, gross margin is used. This is because research using discretionary revenue models is still very little in Indonesia to detect earnings management. One of them is Sari \& Ahmar (2014). Where the research only examines whether there is an indication of earnings management carried out by companies whose shares are listed on the IDX. Meanwhile, researchers are further developing in this research using the conditional revenue model (Stubben, 2010) to detect earnings management carried out by bond issuing companies and then the impact of earnings management itself on bond ratings announced by rating agencies.

Then apart from earnings management, Andry (2005) has proven that several other factors affect the corporate bond rating, which is as follows: Growth, Sinking fund, pledged assets, Debt Maturity, and auditors. Almilia \& Devi (2007) have also proven the factors that influence bond ratings, including size, growth, profitability, liquidity, pledged assets, debt maturity, and auditor size.

Therefore, the researcher will analyze the effect of earnings management, company size, growth, and auditor size on bond ratings of non-financial companies on the Indonesia Stock Exchange. Based on the phenomenon of management actions manipulating earnings in influencing the credit rating agency decision by Zhao (2017) for the USA case after the 1988 capital market crash until the 2008 global financial crisis, this research tries to prove whether this phenomenon also applies to Indonesia by 
utilizing the results of the EM (Earning Management) calculation from Stuben (2010) and bond rating data from PEFINDO on 2012-2016 data. Data considerations that are not until 2018-2019 are considering the conditions of the trade war's effects between the USA and China, which will have a sufficient impact on the EM component of the related Stubben (2010). We are worried that the results of EM calculations will be negative, and of course, this will be difficult to interpret.

\section{Basic Theory and Hypothesis Development}

\subsection{Agency Theory}

Agency theory is a theory used as the primary basis for this research, with the separation of functions between organizational owners and organizational actors. According to Scott (2015), agency theory is a contractual relationship between the principal and agent. It is assumed that each individual is motivated by self-interest, which creates a conflict of interest between the principal and agent. In a company, shareholders are the principal, while the agent is the management who manages the company. Agency theory assumes that each individual is solely motivated by his interests, giving rise to the principal and agent's conflicts of interest.

As an agent, management is expected to sell its bonds in the capital market very well. Where management must provide financial reports as one of the bases for valuation for rating securities agents. In practice, management is responsible for providing financial reports where the accounting standards require accrual-based accounting reporting. Management can manage the financial reports it makes to achieve specific goals by performing earnings management. These things encourage managers to carry out earnings management to achieve their goals. Then in Yasa (2010), Sari \& Bandi (2010) also describes one more theory that underlies their research: signaling theory. Signaling theory shows information asymmetry between company management and other parties with interest in certain information. Signaling theory explains why companies present information to the public (Wolk \& Tearney, 2001: 308). This information can be in financial reports, company policy information, or other 
information voluntarily submitted by the company management. Signaling theory suggests how a company should provide signals to users of financial reports. This signal is in the form of information regarding what management has done to realize the owner's wishes. The signal can be in the form of promotion or other information, which states that it is better than other companies (Machfoedz, 1999).

Signaling theory explains why the company provides financial report information to external parties related to the asymmetry of information between company management and outsiders where the company management has more information and knows the company's prospects in the future. In the aspects that have been provided by management for rating agencies, it is also a signal for rating agencies in the rating of bonds issued. In several studies, it has also been stated that the results of bond ratings and changes in credit ratings are also a source of information for investors. Bond ratings provide information about the issuer's financial performance and business position. Because the rating assessment considers financial and non-financial factors, bond ratings can also provide investors with signals in making decisions.

\subsection{Earning Management}

Sugiri (1998) divides the definition of earnings management into two, namely: a) Narrow definition: earnings management in this case only deals with the choice of accounting method. In this narrow sense, earnings management is defined as the behavior of managers to "play" with the discretionary accruals component in determining the amount of earnings. b) The broad definition of earnings management is a manager's action to increase (reduce) the currently reported profit of a unit for which the manager is responsible, without causing an increase (decrease) in the unit's longterm economic profitability (Widyaningdyah, 2001).

If Sugiri (1998) provides a technical definition of earnings management, Surifah (2001) provides his opinion on the impact of earnings management on financial statements' credibility. According to Surifah (2001), earnings management can reduce the credibility of financial reports when used for decision making because earnings management is a form of manipulation of financial reports, which is a means of 
communication between managers and external parties of the company (Widyaningdyah, 2001).

In practice, Accounting Standards allow managers to choose accounting policies in reporting earnings, but this policy creates opportunities for managers to manage earnings. Gumanti (2002) states that earnings management arises as a direct consequence of managers or financial report makers' efforts to manage accounting information, particularly earnings (earnings), for personal or corporate interests. Holtausen and Leftwitch (1983) reveal two perspectives of earnings management: opportunistic earnings management and informative earnings management. Earnings management is opportunistic if the manager uses the technique only to maximize his gain. On the other hand, earnings management is informative if the manager aims to disclose information and accurate projections regarding the company's cash flow. Scott (2015) also suggests several earnings management patterns by managers, including Taking a Bath, Income Minimization, Income Maximization, and Income Smoothing (Sari \& Bandi, 2010).

According to Watts \& Zimmerman (1990), three hypotheses encourage earnings management: the bonus plan hypothesis, debt covenant hypothesis, and political cost hypothesis. The three hypotheses will also impact the choice of accounting policies chosen by management concerning how the company's financial condition at that time.

\subsection{Bond Rating}

An owner of capital who is interested in buying bonds should pay attention to the bond rating. The rating is a statement about the condition of the debtor and the possibility of what can and will be done concerning Foster's debt (1986). A bond rating is an opinion on the bond issuer's creditworthiness based on the relevant risk factors. The rating assigned is not a recommendation to buy, sell, or maintain a bond. This opinion focuses on the capacity and willingness of the bond issuer to meet its obligations promptly. The opinion given is also not specific to a bond but to the company that issued the bond. The bond rating provides an analysis of the company's creditworthiness so 
that it can be used for a variety of financial and commercial purposes, such as negotiating long-term leases or minimizing letters of credit for vendors (Harsono, 2010).

Of course, an investor interested in buying bonds must pay attention to the bond rating. Rating or rating is a statement about the condition of the debtor and the possibility of what can and will be done in relation to the debt it has, so it can be said that the rating tries to measure the risk of default, namely the opportunity for the issuer or borrower to experience a condition of being unable to meet its financial obligations (Foster, 1986). The corporate bond rating is expected to provide investors clues about the quality of bond investments they are interested in.

\subsection{Hypothesis Development}

Sari \& Bandi (2010) and Zhao (2017) argued that one factor in bond valuation includes financial elements. Hence, companies tend to encourage managers to carry out earnings management concerning issuing bond ratings. The results of the research show that companies that issue bonds are proven to carry out earnings management. The next research that discusses the effect of bond ratings on earnings management indications in a company is Yasa (2010). The research sample for initial bond issuers is all bonds that were first issued on the Jakarta Stock Exchange. This research aims to examine the effect of having to be rated on companies' earnings management that will issue initial bonds. The result is that the information and financial ratios are proven to influence the bond rating. Before the rating is assigned, the company is proven to carry out earnings management.

Then, Kim et al. (2013) also conducted a study on the influence between credit ratings and earnings management for SEC-listed companies from 1990-2011. This study suggests that earnings management has a negative effect on bond ratings. For bond ratings to increase, earnings management is decreasing, and for bond ratings that are found to be decreasing earnings, management is found to be increasing. Yogy and Sari (2010) also researched earnings management and bond ratings with a sample of going public non-financial companies from 2005 to 2009, listed on the Indonesia Stock Exchange. The research results show that the company is proven to manipulate earnings 
through short-term discretionary accruals when issuing bonds. The company is proven to manipulate earnings through long-term discretionary accruals at the time of issuance of bonds. Based on this argument, the following hypotheses can be formulated.

H1: earnings management affects the rating of corporate bonds.

Furthermore, Andry (2005) and Fadah, et al. (2016) examine the Factors Affecting Bond Rating Predictions for manufacturing companies listed on the JSE and SSE and listed in the bond rating issued PEFINDO. The dependent variable is the bond rating, and the independent variables include growth, company size, sinking fund, pledged assets, debt maturity, and auditors. The results of Andry's (2005) research are as follows: Growth is proven to have a positive effect on bond ratings; Company Size proved to not affect bond ratings; Sinking funds are proven to have a positive effect on bond ratings; The pledged asset is proven to have a positive effect on the bond rating; Debt Maturity has a positive effect on bond ratings, and the auditor has a positive effect on bond ratings.

Almilia \& Devi (2007) and Achmad \& Wahyudiani (2019) also examined the factors that influence bond ratings, including size, growth, profitability, liquidity, pledged assets, debt maturity, and auditor size in companies listed on the Surabaya Stock Exchange. The results of the research are as follows: Growth affects predicting corporate bond ratings, company size does not affect predicting corporate bond ratings, profitability does not affect predicting bond ratings, liquidity does not affect predicting corporate bond ratings, guarantees (Secure). ) does not affect predicting corporate bond ratings, the maturity of bonds (maturity) has no effect in predicting corporate bond ratings, and auditor reputation has no effect in predicting corporate bond ratings. Based on the findings from the discussion above, it can be seen that beside earnings management that has affected to bond rating, then the size, growth of the company will also affect the decision of the securities rating agent as well as the size of the KAP to audit. Then the following hypotheses can be formulated:

H2: Company size affects the corporate bond rating

H3: Company growth affects the corporate bond rating

H4: Auditor size affects the corporate bond rating. 


\section{Research Method}

\subsection{Population and Sample Selection Technique}

The population in this study's object are companies listed on the Indonesia Stock Exchange (IDX). They have published their annual reports on the IDX in 2012-2016 and bond ratings of non-financial companies listed on the IDX Over The Counter - Fixed Income Service (OTC-FIS). Published in the Indonesia Bonds Market Directory (IBMD) in 2012-2016. While the research sample is non-financial companies listed on the IDX. The sampling technique is based on a purposive sampling method. The criteria for selecting the sample are as follows:

a) Bonds listed on the IDX OTC-FIS which are listed in the 2012-2016 IBMD.

b) It is a non-financial company in Indonesia.

c) The company has conducted an Initial Public Offering (IPO), is not included in the de-listing list, and has stopped trading by the OJK and reports the complete audited financial report during the observation period.

\subsection{Operational Variable Definition}

\subsubsection{Dependent Variable}

Table 1.

Bond Rating Scale

\begin{tabular}{|c|c|c|c|}
\hline $\begin{array}{c}\text { Bond } \\
\text { Ratings }\end{array}$ & Scale & $\begin{array}{c}\text { Bond } \\
\text { Ratings }\end{array}$ & Scale \\
\hline AAA & 19 & BB+ & 9 \\
\hline AA+ & 18 & BB & 8 \\
\hline AA & 17 & BB- & 7 \\
\hline AA- & 16 & B+ & 6 \\
\hline A+ & 15 & B & 5 \\
\hline A & 14 & B- & 4 \\
\hline A- & 13 & CCC+ & 3 \\
\hline BBB+ & 12 & CCC & 2 \\
\hline BBB & 11 & CCC- & 1 \\
\hline BBB- & 10 & D & 0 \\
\hline
\end{tabular}


The dependent variable in this study is the bond rating. The measurement of this bond rating uses an interpretation from the research of Gu \& Zhao (2006), which uses codes 19 to 1 with the intention of a high weight representing a higher rating. Seen in Table 1.

\subsubsection{Independent Variable: Earnings management}

The independent variable in this study is earnings management using discretionary revenue calculations based on the Stubben model (2010), where the value of earnings management is proxied by discretionary revenue (DCREV), which is obtained from the residual equation below, which has been modeled by Stubben (2010).

$\mathrm{EM}$

$$
\begin{aligned}
& =\Delta \mathrm{AR}_{\mathrm{it}}-\alpha+\beta_{1} \Delta \mathrm{R}_{\mathrm{it}}+\beta_{2} \Delta \mathrm{R}_{\mathrm{it}} \mathrm{XSIZE} \mathrm{E}_{\mathrm{it}}+\beta_{3} \Delta \mathrm{R}_{\mathrm{it}} \mathrm{x} \mathrm{AGE}_{\mathrm{it}}+ \\
& \beta_{4} \Delta \mathrm{R}_{\mathrm{it}} \mathrm{xAGE} \_\mathrm{SQ} \mathrm{it}_{\mathrm{it}}+\beta_{5} \Delta \mathrm{R}_{\mathrm{it}} \mathrm{xGRR} \mathrm{N}_{\mathrm{it}}+\beta_{6} \Delta \mathrm{R}_{\mathrm{it}} \mathrm{xGRM} \mathrm{Git}_{\mathrm{it}}+ \\
& \beta_{7} \Delta R_{\text {it }} x G R M \_S Q_{i t}+\varepsilon_{\text {it }}
\end{aligned}
$$

Where :

$\begin{array}{lll}\text { EM } & = & \text { earning management } \\ \Delta & = & \text { annual change } \\ \text { AR } & = & \text { end year account receivable } \\ \text { R } & = & \text { annual revenue } \\ \text { SIZE } & = & \text { end year log of total asset } \\ \text { AGE } & = & \text { company age (year) } \\ \text { GRR_N } & = & \text { median of revenue growth } \\ \text { GRM } & = & \text { median of gross profit growth } \\ \text { _SQ } & = & \text { the square of the variable } \\ \varepsilon & = & \text { error }\end{array}$

\subsubsection{Independent Variables: Size, Growth, and Auditor Size}

Firm size (size) describes the ownership of the stakeholder base. If the company is large, it has a broader interest base and vice versa. Various company policies will have a more significant impact on public interests than small companies. This study uses the natural logarithmic formula of total assets based on Cornett et al. (2008) research.

The growth variable used in this study is following Andry's (2005) research, namely looking at growth based on the company's growth opportunities as measured by using the market to book ratio. A dummy variable will be used in measuring the auditor 
size variable, as was done in Andry's (2005) study. Where companies whose financial statements have been audited by the big 4 Public Accounting Firm (KAP) (Price Waterhouse Coopers, Ernst \& Young, Deloitte, and KPMG) will be given a value of one, while companies whose financial statements have been audited by KAP other than big four will be given a zero value

\subsection{Data Analysis Method}

The data analysis method proving the effect of earnings management, size, growth, and auditor size on bond ratings is multiple regression. In this study, hypothesis testing used multiple regression equation models, namely:

$$
\text { Rating }=\alpha+\beta_{1} E M+\beta_{2} \text { Size }+\beta_{3} \text { Growth }+\beta_{4} \text { Auditor }+\varepsilon
$$

Where :

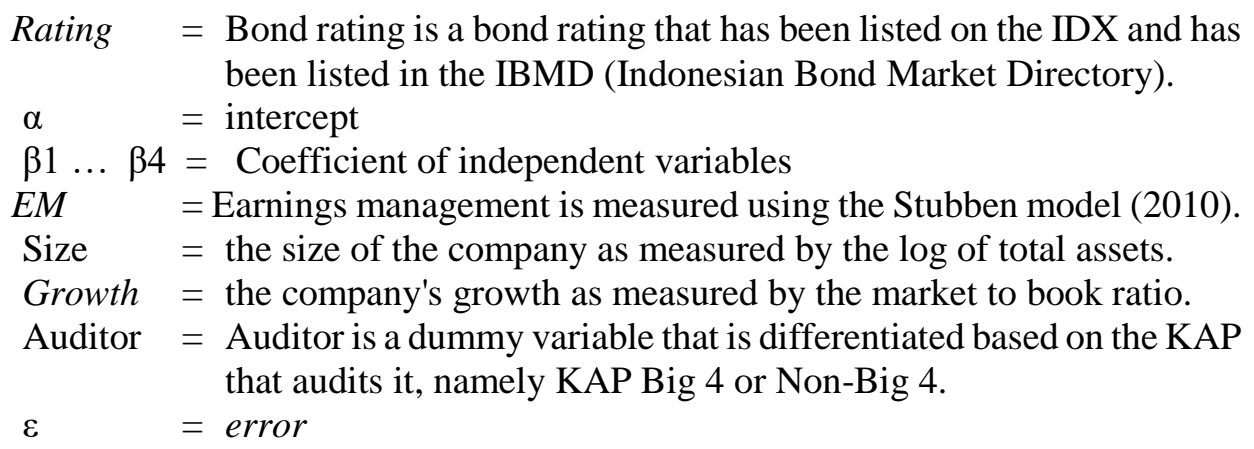

The alternative hypothesis $1-4$ will be accepted if the coefficients $\beta 1, \beta 2, \beta 3$, and $\beta 4$ have t-count values greater or less than t-table and are considered significant at the $5 \%$ significance level. If the test results show the probability value (sig.) $>\alpha(0.05)$, then Ho is accepted, meaning that each independent variable does not have a significant effect on the dependent variable. Conversely, if the test results show the probability value (sig.) $<\alpha(0.05)$, then Ho is rejected, meaning that each independent variable has a significant effect on the dependent variable. 


\section{Result and Discussion}

\subsection{Overview of the Observation Unit}

Based on the established criteria, 30 companies were selected as samples in this study. The list of the number of companies that meet the criteria and become samples can be seen in table 2 .

Table 2.

Sample Selection Results

\begin{tabular}{|c|l|c|}
\hline No. & \multicolumn{1}{|c|}{ Criterion } & $\begin{array}{c}\text { Number of } \\
\text { Samples }\end{array}$ \\
\hline 1. & $\begin{array}{l}\text { The bonds are listed on the IDX OTC-FIS, listed in the } \\
\text { Indonesian Bond Market Directory (IBMD) 2012-2016. }\end{array}$ & 111 \\
\hline 2. & It is a financial company in Indonesia. & $(56)$ \\
\hline 3. & $\begin{array}{l}\text { The company has made an IPO (Initial Public Offering) or sale } \\
\text { of shares to outside parties }\end{array}$ & $(20)$ \\
\hline 4. & $\begin{array}{l}\text { It does not include companies in the de-listing list and has been } \\
\text { stopped trading by the OJK and publishes complete audited } \\
\text { financial reports during the observation period. }\end{array}$ & $(5)$ \\
\hline & Total companies sampled & $\mathbf{3 0}$ \\
\hline
\end{tabular}

\subsection{Initial Detection of Earnings Management}

Table 3.

Development of Earnings Management with Conditional Revenue Model

\begin{tabular}{|c|c|c|c|c|c|c|c|}
\hline No. & Industry Sector & Mean & $\mathbf{2 0 1 2}$ & $\mathbf{2 0 1 3}$ & $\mathbf{2 0 1 4}$ & $\mathbf{2 0 1 5}$ & $\mathbf{2 0 1 6}$ \\
\hline 1 & Agriculture & $-0,3799$ & $-0,3116$ & $-0,3303$ & $-1,4350$ & 0,1732 & 0,0040 \\
\hline 2 & Infrastructure & 0,3417 & $-0,1237$ & 0,0453 & 0,3095 & 0,1397 & 1,3378 \\
\hline 3 & Chemical & 0,0574 & $-0,1454$ & 0,1271 & $-0,0332$ & 0,2205 & 0,1179 \\
\hline 4 & Construction & 0,3946 & 0,5165 & 0,0624 & 0,5227 & 0,3668 & 0,5044 \\
\hline 5 & Food and Beverage & $-0,0812$ & $-0,1532$ & 0,1285 & $-0,3938$ & 0,0348 & $-0,0222$ \\
\hline 6 & Tourism & 0,0131 & 0,0438 & $-0,0541$ & 0,0465 & $-0,0141$ & 0,0431 \\
\hline 7 & Mining & $-0,0771$ & 0,0235 & 0,0198 & $-0,1818$ & $-0,6113$ & 0,3641 \\
\hline 8 & Real Estate & $-0,0731$ & $-0,1359$ & $-0,2165$ & $-0,2201$ & 0,0807 & 0,1264 \\
\hline 9 & Telecommunication & $-0,0405$ & 0,1128 & 0,4855 & $-0,2206$ & 0,0815 & $-0,6618$ \\
\hline 10 & Transportation & 0,1488 & $-0,1264$ & 0,2865 & 0,0446 & 0,3428 & 0,1966 \\
\hline
\end{tabular}


Based on table 3, it can be seen that as a whole during the 2012-2016 period, the average value of accrual earnings management experienced an increase and a decrease. Ten industrial sectors are the research object, and six of them are indicated by accrual earnings management. It can be seen because the value of accrual earnings management from the six industries is less than -0.075 or greater than 0.075 from Roychowdhury (2006). It also proves that the highest average value is owned by the construction industry sector, which means that it is indicated by accrual earnings management, and the lowest average value owned by the agricultural sector, which is also indicated by accrual earnings management.

Table 4.

Value Classification of Accrual Earnings Management (EMA)

\begin{tabular}{|c|l|c|c|c|c|c|c|c|}
\hline No. & $\begin{array}{c}\text { Classificati } \\
\text { on }\end{array}$ & Status & $\mathbf{2 0 1 2}$ & $\mathbf{2 0 1 3}$ & $\mathbf{2 0 1 4}$ & $\mathbf{2 0 1 5}$ & $\mathbf{2 0 1 6}$ & Total \\
\hline 1 & $<-0,075$ & $\begin{array}{c}\text { Indication of } \\
\text { EMA }\end{array}$ & 18 & 11 & 16 & 9 & 8 & 62 \\
\hline 2 & $\begin{array}{l}-0,075 \mathrm{~s} / \mathrm{d} \\
0,075\end{array}$ & $\begin{array}{c}\text { No indication of } \\
\text { EMA }\end{array}$ & 4 & 12 & 9 & 9 & 9 & 43 \\
\hline 3 & $>0,075$ & $\begin{array}{c}\text { Indication of } \\
\text { EMA }\end{array}$ & 8 & 7 & 5 & 12 & 13 & 45 \\
\hline & \multicolumn{2}{|c|}{ Total } & 30 & 30 & 30 & 30 & 30 & 150 \\
\hline
\end{tabular}

Furthermore, based on table 4, the number of companies indicated accrual earnings management in 2012 was 26 companies out of a total of 30 companies. Then for 2013 , 18 companies indicated accrual earnings management. Furthermore, the companies indicated to have performed accrual earnings management for 2014 to 2016 were 21 companies. The indicated percentage of accrual earnings management during 2012 2016 was $71 \%$. Meanwhile, in 2012 there was no indication of earnings management as many as four companies.

Then in 2012, as many as 12 companies did not indicate any earnings management. Furthermore, nine companies that are not indicated to carry out accrual earnings management for 2014 to 2016. The percentage of companies not indicated to have performed accrual earnings management during 2012-2016 is $29 \%$. The percentage of 
companies indicated that earnings management is greater. So it can be concluded that by using the conditional revenue model from Stubben (2010), most of these nonfinancial companies are indicated by earnings management.

\subsection{Descriptive Statistics}

Table 5 shows that the EM variable has a minimum value of -2.14640 , a maximum value of 5.47648, an average of -0.00075 , and a standard deviation of 0.67953 . With an average of -0.00075 close to the minimum value, it means that the sample used on average has a low EM value. While the standard deviation of 0.67953 shows a small standard deviation.

Table 5

Result of Descriptive Statistics

\begin{tabular}{|l|c|r|r|r|r|}
\hline & $\mathrm{N}$ & Minimum & Maximum & Mean & Std. Deviation \\
\hline EM & 150 & -2.14640 & 5.47648 & -0.00075 & 0.67953 \\
Size & 150 & 12.0 & 14.3 & 13.076 & 0.4928 \\
Growth & 150 & 0.06159 & 18.11536 & 2.43414 & 2.90730 \\
Rating & 150 & 12 & 19 & 14.81 & 1.800 \\
Valid N (listwise) & 150 & & & & \\
\hline
\end{tabular}

The size variable has a minimum value of 12.0 , a maximum value of 14.3 , an average of 13,076 , and a standard deviation of 0.4928 . With an average of 13,076 close to the maximum value, the sample used on average has a size that is not too high but not too low. While the standard deviation of 0.4928 indicates a small standard deviation. This means that the size value of the sample companies does not vary. Growth has a minimum value of 0.06159 , a maximum value of 18.11536 , an average value of 2.43414 , and a standard deviation of 2.90730 .

With an average value of 2.43414 , the sample used has a reasonably small company size. While the standard deviation of 2.90730 indicates a large standard deviation. This means that the size of the companies in the sample companies is relatively varied. The rating variable has a minimum value of 12 , a maximum value of 19 , an average of 14.81 , and a standard deviation of 1.80 . With an average of 14.81 , the 
sample used on average has a rating that is not too high but not too low. While the standard deviation of 1.80 indicates a small standard deviation. This means that the rating value in the sample does not vary relatively.

\subsection{Alternative Hypothesis Testing}

The multiple regression model equation testing was carried out using the SPSS version 23.0 computer program. The following is table 6 . for the results of testing the calculation of the multiple regression model:

Table 6

Multiple Regression Result

\begin{tabular}{|c|c|c|c|c|c|c|}
\hline \multirow{2}{*}{\multicolumn{2}{|c|}{ Model }} & \multicolumn{2}{|c|}{$\begin{array}{c}\text { Unstandardized } \\
\text { Coefficients }\end{array}$} & \multirow{2}{*}{$\begin{array}{l}\text { Standardized } \\
\text { Coefficients } \\
\text { Beta } \\
\end{array}$} & \multirow[b]{2}{*}{$\mathrm{t}$} & \multirow[b]{2}{*}{ Sig. } \\
\hline & & B & Std. Error & & & \\
\hline \multirow[t]{5}{*}{1} & (Constant) & .036 & 3.436 & & 3.212 & .002 \\
\hline & Earnings Management & -.130 & .174 & -.049 & -.745 & 457 \\
\hline & Size & 1.914 & 263 & .524 & 7.272 & .000 \\
\hline & Growth & .213 & .042 & .344 & 5.054 & .000 \\
\hline & Auditor Size & 651 & 251 & .181 & 2.591 & .011 \\
\hline
\end{tabular}

a. Dependent Variable: Rating

From the regression equation above, it can be explained that the constant is 0.036 . This means, if the independent variables, namely Earnings Management (EM), size, growth, and auditor size, are equal to zero or negligible, then the magnitude of the rating is 0.036 . The EM regression coefficient shows the value of -0.13 and insignificant. It means that there will be no effect from EM toward bond rating. The size regression coefficient shows a value of 1.914 , meaning that there will be a positive correlation between size and rating. If the company's size increases by 1 unit and other variables are considered constant, the rating will increase by 1.914 units. The growth regression coefficient shows a value of 0.213 , meaning that there will be a positive correlation between growth and rating. If growth increases by 1 unit and other variables are considered constant, the rating will increase by 0.213 units.

The regression coefficient for auditor size shows a value of 0.651 , which means there will be a positive correlation between auditor size and rating. If the auditor size 
variable increases by 1 unit and other variables are considered constant, the rating will increase by 0.651 .

Based on the research results in table 6, it can be seen that EM has a significance value of 0.457 , which means $>\alpha(0.05)$, so that $\mathrm{H} 1$ is not supported by research data, meaning that EM does not significantly affect the rating. This is because the primary purpose of companies registering bond ratings to be rated is so that potential bond investors know sufficient information about the state of the company's bonds or do not experience information asymmetry. The bond rating not only focuses on the company's earnings management but instead on the information on the bonds to be sold. Size has a significance value of 0.000 , which means $<\alpha(0.05)$, meaning that the size of the company (size) has a significant effect on the rating with a confidence level of $95 \%$ so that $\mathrm{H} 2$ can be accepted. Statistically, it can be explained that the company's size has a significant effect on the bond rating owned by the company. This indicates that the rating of securities makes measuring firm size based on total assets a focus. These results also prove that the larger the company's size as seen based on total assets, the better the bond rating announced. Elton and Gruber (1995) suggest that the greater the size of a company, the stronger the ability to survive financial distress situations. The bigger a company will be able to reduce the risk of default (default risk); therefore, the rating of bonds to be issued by the securities rating will be even higher.

Growth has a significance value of 0.000 , which means $<\alpha(0.05)$, which means that company growth (Growth) has a significant effect on the rating with a confidence level of $95 \%$ so that $\mathrm{H} 3$ is also accepted. Statistically, it can be explained that the level of growth (growth) of a company has a significant effect on the bond rating. The more the company grows, the higher the bond rating. With growth, the company has investment opportunities, which means that the company promises to provide a return on the investment made. The company can continue to pay the principal and bond interest smoothly using the investment's profit. Because of the company's higher growth, the bond rating will be given a good rating (investment grade).

The fourth hypothesis (H4) states that auditor size is an appropriate predictor of bond ratings. The results show that the value of the auditor size on the rating has a 
significance value of 0.011 , which means that the auditor's size significantly affects the rating variable. This implies a close relationship between any auditing KAP and the bond ratings issued by the securities rating. Sari and Murtini (2015) prove that quality KAP can significantly affect bond ratings. The results of this study support the current test results that a quality KAP influences bond ratings. Therefore, the accounting firm's size that provides an audit opinion on the company's financial statements has a role in the rating decision by the securities rating agency. Big KAP 4 is believed to produce quality audit opinions and be accountable for the public interest.

\subsection{Discussion on Alternative Hypothesis Testing}

\subsubsection{Earnings Management and Bond Rating}

From the statistical results, it is found that earnings management has a negative effect on bond ratings, where if the level of earnings management, the resulting bond rating will be low. The implied negative relationship between EM and bond ratings is in line with the results found by Crabtree et al. (2014). Following Roychowdhury's (2006) argument that earnings manipulation cannot serve as a reliable measure of firm performance for investors and bondholders, it masks firm performance by distorting earnings quality and increasing information asymmetry, can be interpreted as opportunistic behavior of the manager's name. In a way, EM represents abnormal business decisions from management and leads to these activities, such as overproduction, sales manipulation, and discretionary spending reduction. Therefore, increasing EM risk can result in a lower credit rating.

Although the hypothesis is in line with previous research, the regression equation's insignificance cannot further prove that there is a significant effect of EM on bond ratings, which is also shown by research from Wajnsztajn \& Heintz (2016). In the Indonesian context, it is challenging to connect $\mathrm{EM}$ and bond ratings because companies do EM more than just trust investors and shareholders. It is not to improve relations with creditors considering the already high rating, which is an average of $14 \mathrm{a}$ or scale A. This result is different from Zhao (2017) because of differences in the sample; namely, this study is dominated by companies with good ratings, while Zhao (2017) is the opposite. 


\subsubsection{Size and Bond Rating}

The statistical results found that company size had a positive effect on bond ratings and the results were significant. This means that it can be concluded that $\mathrm{H} 2$ is successfully supported so that hypothesis 2 is accepted. This means that the larger the company's size, the more likely it is that the bonds issued will have a high rating. The greater the company's total assets, the more it is expected to have the ability to pay off liabilities in the future (Setyapurnama \& Norpratiwi, 2004). Given the large amount of assets that can be used as collateral for bond issuance. This information is useful for reducing the level of uncertainty that investors have. This study's results are following research by Alwi \& Nurhidayati (2012) and Winardi (2013), who found that company size has a significant effect on the prediction of bond ratings. It means that firm must reach the larger condition or have the capability to expand to get a high bond rating from Credit Rating Agency such as PEFINDO in the Indonesia context.

\subsubsection{Growth and Bond Rating}

The statistical results found that company growth had a positive effect on bond ratings and the results were significant. This means that it can be concluded that $\mathrm{H} 3$ has been successfully supported so that hypothesis 3 is accepted. This shows that the company growth variable, as measured by the market to book value ratio, is a significant indicator for assessing securities rating agents. The company's growth is considered acceptable; the issuing company will also receive an investment-grade bond rating. This research is in line with Almilia \& Devi (2007) (Burton et al., 1998) and Widya (2005), which state that company growth has a significant positive effect on bond rating. It means that firm must reach the growing condition to get a high bond rating from Credit Rating Agency such as PEFINDO in the Indonesia context.

\subsubsection{Auditor Size and Bond Rating}

From the statistical results, it was found that the size of the company's auditors had a positive effect on bond ratings and the results were significant. This means that it can 
be concluded that $\mathrm{H} 4$ has been successfully supported so that hypothesis 4 is accepted. The auditor's reputation has a positive effect on the higher the bond rating, and vice versa, the lower the auditor's reputation, the lower the bond rating will be. One of the critical information for rating agencies in considering their decisions is the audited financial statements, which will provide an overview of transparent financial reports. This is because the reports produced by KAP big four are considered to be more independent and describe the company's actual condition so that the securities rating agent will have a higher level of trust with the company's financial statements. A more independent opinion produced by KAP big four is considered to reduce agency risk and reduce default risk, which will increase the company's bond rating (Sunarjanto \& Tulasi, 2013). This study's results are in line with Andry (2005) and (Restuti \& Aldo, 2010), which states that the reputation of KAP has a significant positive effect on bond ratings.

\section{Conclusion, Implication, and Limitation}

\subsection{Conclusion}

This study examines whether earnings management, company size, company growth, and auditor size affect bond ratings. In testing, the research object used a sample of 30 non-financial companies that have issued initial bonds during the 2012-2016 period. The method used to analyze the data in this study is multiple linear regression; based on the analysis results in the previous chapter, empirical evidence has been obtained that earnings management does not affect the rating of corporate bonds listed on the Indonesia Stock Exchange in 2012-2016. Furthermore, company size has a positive and significant effect on the rating of corporate bonds listed on the Indonesia Stock Exchange in 2012-2016.

Then from 30 samples of companies listed on the Indonesia Stock Exchange in 2012-2016, it is also proven that growth is positive and significant on bond ratings. This study also proves that auditor size also has a positive and significant effect on the rating of corporate bonds listed on the Indonesia Stock Exchange in 2012-2016. The most important finding is that the quality of the audit results will determine the obligation 
rating. It is for these audit quality results that sometimes, earnings management actions occur. In this way, it has been revealed that earnings management's action is to maintain a positive signal for investors and shareholders and not to bondholders or creditors.

\subsection{Implication and Limitation}

In this study, the authors realize that there are many limitations and shortcomings. In this study, the samples used were 30 companies. These companies are non-financial companies listed on the IDX, and their bond ratings are listed on the OTC FIS IDX in the 2012-2016 period. This study uses a bond rating variable. The research period is only five years, so very few samples can be studied because not many companies that have gone public sell their bonds on the capital market, and not every year, the company issues bonds. Therefore it is felt that this research period is considered relatively short. Suggestions for further research are to research for a longer period, for example, eight years, to represent the non-financial companies to be studied.

In this study, the rating of the primary bond as the dependent variable has been assigned the rating agency's rating. Elements such as some financial information and other financial ratios other than a book to market ratios are not discussed in detail in this study. Suggestions for further research are to add independent variables such as operating profit, retained earnings, operating cash flow, liquidity, and leverage in measuring the relationship or influence on bond ratings and company stock returns.

This study uses independent variable earnings management, but it cannot influence the dependent variable bond rating and company returns. It is hoped that further research can be developed to examine the relationship between earnings management and other variables, such as company earnings and its relationship with tax avoidance.

\section{References}

Ahmad, N.G., \& Wahyudiani. (2019). Analisis Determinan Obligasi Korporasi. Jurnal Aplikasi Bisnis dan Manajemen, Vol 5. No.3, September,361-372, /DOI: http://dx.doi.org/10.17358/jabm.5.3.361. 
Almilia, L. S., \& Devi, V. (2007). Faktor-Faktor yang Mempengaruhi Prediksi Peringkat Obligasi Pada Perusahaan Manufaktur Yang Terdaftar Di Bursa Efek Jakarta. Proceeding Seminar Nasional Manajemen SMART Bandung, November, 1-23.

Alwi, A., \& Nurhidayati. (2012). Analisis Faktor Faktor Yang Mempengaruhi Peringkat Obligasi (Studi Empiris: Perusahaan Manufaktur Yang Terdaftar Di Bei Periode 2008-2011). Universitas Semarang.

Andry, W. (2005). Analisis Faktor-Faktor Yang Mempengaruhi Prediksi Peringkat Obligasi. Buletin Ekonomi Moneter Dan Perbankan, 243-262. https://doi.org/10.21098/bemp.v8i2.135

Burton, B., Adams, M., \& Hardwick, P. (1998). The Determinants of Credit Ratings in the United Kingdom Insurance Industry. Journal of Business Finance \& Accounting, 30, 539-572. https://doi.org/10.1111/1468-5957.00007

Crabtree, A., Maher, J. J., \& Wan, H. (2014). New debt issues and earnings management. Advances in Accounting, 30(1), 116-127. https://doi.org/https://doi.org/10.1016/j.adiac.2014.04.005

Fadah, I., Zania, S.I.W \& Puspitasati, N. (2016). Determinan Peringkat Obligasi Perusahaan di Indonesia. UNEJ e-Proceeding, [S.1.], p. 345-354, dec. 2016. ISSN 2686-0783. Available at: <https://jurnal.unej.ac.id/index.php/prosiding/article/view/3673>. Date accessed: 29 aug. 2020.

Gu, Z., \& Zhao, Y. (2006). Accruals, Income Smoothing, and Bond Ratings. European Accounting Association Annual Congress and Seminars, 1-39. https://doi.org/10.2139/ssrn.817506

Gumanti, T. A. (2002). Earnings Management Dalam Penawaran Saham Perdana di Bursa Efek Jakarta. Kumpulan Makalah SNA V, 124-148.

Harsono, A. S. (2010). Pengaruh current ratio, debt-to-equity ratio,Return on assets dan ukuran perusahaan Terhadap peringkat obligasi. In Universitas Indonesia.

Hätty, D., \& Åkesson, J. (2015). Accounting Quality in Private Firms: The Impact of Professional Directors. Department of Accounting: Master's Thesis in Accounting and Financial Management, STOCKHOLM SCHOOL OF ECONOMICS.

Kim, Y. S., Kim, Y., \& Song, K. R. (2013). Credit rating changes and earnings management. Asia-Pacific Journal of Financial Studies, 42(1), 109-140. https://doi.org/10.1111/ajfs.12007

Restuti, \& Aldo, M. G. (2010). Pengaruh Mekanisme Corporate Governance Terhadap Peringkat dan Yield Obligasi. Prosiding Seminar Nasional Dan Call For Paper. 
Roychowdhury, S. (2006). Earnings management through real activities manipulation. Journal of Accounting and Economics, 42(3), 335-370. https://doi.org/10.1016/j.jacceco.2006.01.002

Sari, N. H., \& Ahmar, N. (2014). Revenue Discretionary Model Pengukuran Manajemen Laba: Berdasarkan Sektor Industri Manufaktur di Bursa Efek Indonesia. Jurnal Akuntansi Dan Keuangan, 16(1), 43-51. https://doi.org/10.9744/jak.16.1.43-51

Sari, S. R. K., \& Bandi. (2010). Praktik Manajemen Laba terkait Peringkat Obligasi. Simposium Nasional Akuntansi (SNA) XIII Purwokerto, 1-18. http://repositorio.unan.edu.ni/2986/1/5624.pdf

Scott, W. R. (2015). Financial Accounting Theory. Seventh Edition.

Setyapurnama, Y. S., \& Norpratiwi, A. M. V. (2004). Pengaruh Corporate Governance terhadap Peringkat Obligasi dan Yield Obligasi.

Stubben, S. (2010). Discretionary Revenues as a Measure of Earnings Management. The Accounting Review, 85, 695-717. https://doi.org/10.2139/ssrn.1135811

Sugiri, S. (1998). Earning Management: Teori Model dan Bukti Empiris ,. Telaah, 1-18.

Sumanti, E. R. (2018). The analysis of the determinants and consequences of earnings game mechanism interplay: international evidence. In Universitas, Indonesia.

Sunarjanto, N., \& Tulasi, D. (2013). Kemampuan Rasio Keuangan Dan Corporate Governance Memprediksi Peringkat Obligasi Pada Perusahaan Consumer Goods. Jurnal Keuangan Dan Perbankan, 17(2), 230-242.

Surifah, S. (2001). Studi tentang Indikasi Unsur Manajemen Laba pada Laporan Keuangan Perusahaan Publik di Indonesia. Jurnal Akuntansi Dan Auditing Indonesia, 5(1), 8199. https://journal.uii.ac.id/JAAI/article/view/11383

Wajnsztajn, P., \& Heintz, C. (2016). Earnings Management and the Cost of Publicly Issued Debt. Department of Business Administration, 11-577. http://lup.lub.lu.se/luur/download?func=downloadFile\&recordOId=8886212\&fileOId $=8886218$

Watts, R., \& Zimmerman, J. (1990). Positive Accounting Theory: A Ten Year Perspective. Accounting Review, 65(1), 131-156.

Widyaningdyah, A. U. (2001). Factors Analysis Affecting Earnings Management on Go Publuc Companies in Indonesia. Jurnal Akuntansi \& Keuangan, 3(2), 89-101.

Winardi, R. D. (2013). The Influence of Individual and Situational Factors on Lower-Level Civil Servants' Whistle-Blowing Intention in Indonesia. Jurnal Ekonomi \& Bisnis Indonesia (Fakultas Ekonomi Dan Bisnis Universitas Gadjah Mada), 28(3), 361-376. https://doi.org/10.22146/jieb.6216 
The Indonesian Journal of Accounting Research - Sept, Vol. 23 , No.3 , 2020

Wolk, H. I., \& Tearney, M. G. (2001). Accounting theory: a conceptual and institutional approach. 4th edition.

Yasa, G. W. (2010). Pemeringkatan Obligasi Perdana Sebagai Pemicu Manajemen Laba : Bukti Empiris Dari Pasar Modal Indonesia. Simposium Nasional Akuntansi XIII, 1-29.

Zhao, Q. (2017). Do Manager Manipulate Earning to Influence Credit Rating Agency Decision? Review of Accounting and Finance, Vol.16. No.3, 366-384; https://doi.org/10.1108/RAF-05-2016-007

Zhu, X., \& Lu, S. (2013). Earnings management through real activities manipulation before mergers and acquisitions. Journal of Finance and Accountancy Earnings, 1-6. 